\title{
Morphological cladistic analysis of Pseudobombax Dugand (Malvaceae, Bombacoideae) and allied genera
}

\author{
JEFFERSON GUEDES DE CARVALHO-SOBRINHO ${ }^{1}$ and \\ LUCIANO PAGANUCCI DE QUEIROZ ${ }^{1,2}$
}

(received: January 20, 2010; accepted: May 5, 2011)

\begin{abstract}
Morphological cladistic analysis of Pseudobombax Dugand (Malvaceae, Bombacoideae) and allied genera). Pseudobombax Dugand belongs to the family Malvaceae subfamily Bombacoideae and aggregates 29 species restricted to the Neotropics. A morphological cladistic analysis of Pseudobombax and allied genera was carried out to test the monophyly of the genus and to provide hypotheses on its phylogeny. Parsimony analyses were based on 40 morphological characters and 28 species, 14 belonging to Pseudobombax and 14 to other species of Bombacoideae, Matisieae (Malvoideae) and Ochromeae. Nine most parsimonious trees (144 steps, ci 0.40, ri 0.67) were produced when 10 multistate characters were taken as ordered while only two most parsimonious trees (139 steps, ci 0.41 , ri 0.67$)$ were obtained when all characters were considered as unordered. Pseudobombax monophyly had moderate bootstrap support, appearing as sister to a clade composed of the genera Bombacopsis Pittier and Pachira Aubl., or to the genus Bombax L. according to the analysis. The petiole widened at the apex and the leaflets not jointed to the petiole are probably synapomorphies of Pseudobombax. Three main clades were found in the genus: one characterised by petiolulated leaflets and 5-angular fruits, the other by pubescent leaves and calyx, and the other by reduction of the number of leaflets. The latter includes species endemic to the Brazilian semi-arid region also characterised by the absence of phalanges in the androecium. Interspecific affinities in Pseudobombax as well as the morphological evolution in Bombacoideae are discussed.
\end{abstract}

Key words - biogeography, evolution, morphology, phylogeny, taxonomy

RESUMO - (Análise cladística morfológica de Pseudobombax Dugand (Malvaceae, Bombacoideae) e gêneros relacionados). O gênero Pseudobombax Dugand pertence à família Malvaceae, subfamília Bombacoideae, e compreende 29 espécies com distribuição restrita à região Neotropical. Realizou-se uma análise cladística morfológica de Pseudobombax e gêneros relacionados a fim de testar seu monofiletismo e elaborar hipóteses sobre sua filogenia. As análises de parcimônia foram baseadas em 40 caracteres e 28 espécies, sendo 14 de Pseudobombax e as demais pertencentes a Bombacoideae, Matisieae (Malvoideae) e Ochromeae. Foram obtidas nove árvores mais parcimoniosas (144 passos, ci 0,40, ri 0,67) quando 10 caracteres multiestado foram considerados como ordenados e apenas duas árvores mais parcimoniosas (139 passos, ci 0,41, ri 0,67) quando todos os caracteres foram considerados não ordenados. A monofilia de Pseudobombax foi moderadamente sustentada com base na análise de bootstrap, aparecendo como grupo-irmão de um clado formado pelos gêneros Bombacopsis Pittier e Pachira Aubl. ou do gênero Bombax L. de acordo com a análise. As prováveis sinapomorfias de Pseudobombax são o ápice do pecíolo dilatado e os folíolos não articulados com o pecíolo. Foram encontrados três clados principais dentro do gênero: um caracterizado por folíolos peciolulados e frutos 5-angulares, outro caracterizado pela presença de folhas e cálice pubescentes e outro pela redução do número de folíolos. Este último inclui espécies endêmicas da região semiárida do nordeste do Brasil caracterizado também pela ausência de falanges no androceu. Apresenta-se uma discussão sobre as afinidades interespecíficas em Pseudobombax e sobre a evolução morfológica em Bombacoideae.

Palavras-chave - biogeografia, evolução, filogenia, morfologia, taxonomia

\section{Introduction}

Pseudobombax Dugand(Malvaceae, Bombacoideae) comprises 29 species distributed in the Neotropics (Robyns 1963, Fernández-Alonso 2001, CarvalhoSobrinho \& Queiroz 2010, IPNI 2010). It occurs in

1. Universidade Estadual de Feira de Santana, Departamento de Ciências Biológicas, km 03, BR 116, Campus, 44031-460 Feira de Santana, BA, Brazil.

2._Corresponding author: lqueiroz@uefs.br different vegetation types, especially those associated with seasonal climate such as seasonally dry forests and Savanna. The genus is diagnosed by the combination of the trunks with vertical greenish strips, digitately compound and pulvinate leaves clustered in the apex of the branches, leaflets not jointed to the petiole, glandular receptacle, filaments joined in a tube and capsules with abundant kapok (Robyns 1963).

Pseudobombax was segregated from Bombax L. by Dugand (1943). He considered Bombax an American genus characterised by leaflets jointed to the petiole, 
flowers with filaments connate in a tube and calyx caducous in fruit that is a 5-valvate capsule with or without sparse kapok. Species with leaflets not jointed to the petiole, fruits with persistent calyx and copious kapok were thus assigned to his new genus, Pseudobombax. Robyns (1963) and Nicolson (1979) had a different concept of Bombax: they considered Bombax to be an Old World genus and transferred the American species to Bombacopsis Pittier and Pseudobombax. Hence, they recognised Pseudobombax as a New World genus distinct from Bombacopsis.

In traditional taxonomic systems, Pseudobombax was included in the family Bombacaceae (e.g. Cronquist 1981). However, phylogenetic studies based on morphological (Judd \& Manchester 1997) and molecular data (Alverson et al. 1999, Baum et al. 2004) did not support the monophyly of Sterculiaceae, Tiliaceae and Bombacaceae, which are now classified into an expanded Malvaceae (Bayer et al. 1999, Nyffeler et al. 2005). Most of the traditional genera of "Bombacaceae" appears in a clade now classified as subfamily Bombacoideae, sister to subfamily Malvoideae. Together, these two subfamilies form the large Malvatheca clade defined by monothecate anthers (Baum et al. 1998). Genera of tribe Durioneae (Durio Adans. and Neesia Blume) were resolved as sister to genera of the tribe Helictereae, unrelated to Malvatheca clade (Alverson et al. 1999). Genera of the tribe Matisieae (Matisia Bonpl., Phragmotheca Cuatrec. and Quararibea Aubl.) were resolved as part of subfamily Malvoideae (Baum et al. 2004, Nyffeler et al. 2005).

Species assigned to Pseudobombax and allied genera have been classified in the Bombacaceae tribe Adansonieae (Bentham \& Hooker 1862, Schumann 1886, 1895, van den Brink 1924, Hutchinson 1967). Van den Brink (1924) and Robyns (1963) recognised a group of closely related genera composed by Bombax, Bombacopsis, Eriotheca Schott. \& Endl., Pachira Aubl., Pseudobombax, Rhodognaphalon (Ulbr.) Roberty and Rhodognaphalopsis A. Robyns, which they called the Bombax-group. These latter two genera are currently treated as synonyms of Pachira (Alverson 1994, Alverson \& Mori 2002, Fernández-Alonso 1998, 2003, Steyermark \& Stevens 1998). Moreover, the distinction between Pachira and Bombacopsis has been questioned and they were treated as congeneric by Alverson (1994), Alverson \& Steyermark (1997) and Fernández-Alonso (1998).

Baum et al. (2004) and Nyffeler et al. (2005) supported the monophyly of the Adansonieae, although only four genera were sampled in each analysis: Adansonia
L. (two species), Bombax (two), Ceiba Mill. (two) and Pachira (one). In Alverson et al. (1999), Eriotheca ruizii (K. Schum.) A. Robyns and Pseudobombax ellipticum (H. B. K.) Dugand were included. Hence, the monophyly of Pseudobombax was not tested yet, its position in Bombax-group was not established and there is no phylogenetic hypothesis to outline the evolution and biogeography of the genus.

This work aims to investigate the phylogeny of Pseudobombax in order to answer the following questions: is Pseudobombax monophyletic? What is its putative sister group? Is the current classification supported by phylogenetic data? What are the main lines of morphological evolution in the genus? Is there correlation between diversification in the genus and occupation of different Neotropical vegetation types?

\section{Material and methods}

Taxon sampling - We included 14 species of Pseudobombax in the ingroup, representing the widest morphological variation and geographical range in the genus (table 1), including species from Seasonally Dry Tropical Forests $(8$ out of 13 species), Savanna (3/7) and Tropical Rain Forests (3/9). The morphological variation sampled included the amplitude in number of leaflets (one in P. simplicifolium to 10 in P. marginatum), indument of leaflets (glabrous in $P$. campestre to tomentose in $P$. tomentosum), length of flower (6 cm in P. minimum to $22 \mathrm{~cm}$ in P. maximum), organization of androecium in phalanges (absent in $P$. calcicola and present in P. palmeri), indument of staminal tube (glabrous in $P$. grandiflorum to pubescent in P. millei), number of stamens (180 in P. campestre to 1,200 in P. septenatum), ratio length/width of fruit (2.2:1 in P. septenatum to 8:1 in P. calcicola). It was avoided the inclusion of species that are diagnosed based on characters that show great phenotypic plasticity aiming to prevent noise in the analysis.

Eleven species from other genera of the Bombax-group and tribe Adansonieae were also taken as part of the ingroup with the aim of establishing a better supported hypothesis of sister group relationships. These included species of the genera Adansonia (one species), Bombacopsis (two), Bombax (one), Cavanillesia Ruiz \& Pav. (one), Ceiba (two), Eriotheca (three) and Pachira (one). The placement of Cavanillesia is not well established, although Baum et al. (2004) considered that it should be included in Bombacoideae, but this assumption was not tested.

The outgroup, based on Baum et al. (2004), comprised (i) Scleronema Benth., supported as part of a sister group of the Adansonieae; (ii) Matisia, a representative of Matisieae formerly included in "Bombacaceae" and supported in a basal position in the Malvoideae; and (iii) Ochroma Sw., which is 
Table 1. Taxa included in the cladistic analysis, their respective voucher and/or bibliographic source and geographical range.

\begin{tabular}{|c|c|c|}
\hline Taxon & Voucher/Bibliographic source & Geographical range \\
\hline Adansonia digitata $\mathrm{L}$. & $h o-S o b r$ & ntinen \\
\hline $\begin{array}{l}\text { Bombacopsis retusa (Mart. \& Zucc.) } \\
\text { A. Robyns }\end{array}$ & Queiroz 4812 & $\begin{array}{l}\text { Northeastern Brazil (Seasonally Dry } \\
\text { Tropical Forests) }\end{array}$ \\
\hline $\begin{array}{l}\text { Bombacopsis stenopetala (Casar.) A. } \\
\text { Robyns }\end{array}$ & Carvalho-Sobrinho 251 & $\begin{array}{l}\text { Northeastern Brazil (Seasonally Dry } \\
\text { Tropical Forests) }\end{array}$ \\
\hline Bombax ceiba L. & Robyns (1963) & $\begin{array}{l}\text { Asian continent (Seasonally Dry and Rain } \\
\text { Tropical Forests) }\end{array}$ \\
\hline Cavanillesia arborea K. Schum. & $\begin{array}{l}\text { Carvalho-Sobrinho 475, Queiroz } 1035 \text {, } \\
\text { Leite } 301\end{array}$ & $\begin{array}{l}\text { Bolivia, Brazil and Peru (Seasonally Dry } \\
\text { Tropical Forests) }\end{array}$ \\
\hline Ceiba glaziovii (Kuntze) K. Schum. & Queiroz 997, Gibbs \& Semir (2003) & $\begin{array}{l}\text { Northeastern Brazil (Seasonally Dry } \\
\text { Tropical Forests) }\end{array}$ \\
\hline Ceiba pentandra (L.) Gaertn. & $\begin{array}{l}\text { Carvalho-Sobrinho 116, Gibbs \& Semir } \\
\text { (2003) }\end{array}$ & $\begin{array}{l}\text { African and American continent (Tropical } \\
\text { Rain Forests) }\end{array}$ \\
\hline Eriotheca crenulaticalyx A. Robyns & Martins (1993) & Brazil (Atlantic Rain Forest) \\
\hline $\begin{array}{l}\text { Eriotheca gracilipes (K. Schum.) A. } \\
\text { Robyns }\end{array}$ & Carvalho 4007, Robyns (1963) & Brazilian Central Plate \\
\hline $\begin{array}{l}\text { Eriotheca longipedicellata (Ducke) A. } \\
\text { Robyns }\end{array}$ & Robyns (1963) & Brazil (Amazonian Tropical Rain Forests) \\
\hline Matisia ochrocalyx K. Schum. & $\begin{array}{l}\text { Alverson \& Stey } \\
\text { Alverson \& Mo }\end{array}$ & $\begin{array}{l}\text { Costa Rica to Northern Brazil (Tropical } \\
\text { Rain Forests) }\end{array}$ \\
\hline $\begin{array}{l}\text { Ochroma pyramidale (Cav. ex Lam.) } \\
\text { Urb. }\end{array}$ & $\begin{array}{l}\text { Alverson \& Steye } \\
\text { Cascante-Marin }\end{array}$ & $\begin{array}{l}\text { Mexico to Venezuela and Bolivia } \\
\text { (Tropical Rain Forests) }\end{array}$ \\
\hline Pachira aquatica Aubl. & Mattos-Silva 3139, Robyns (1963) & Ecuador and Peru \\
\hline $\begin{array}{l}\text { Pseudobombax calcicola Carv.-Sobr. } \\
\text { \& L. P. Queiroz }\end{array}$ & $\begin{array}{l}\text {-8152, Carvalho- } \\
\text { arvalho-Sobrinho } 573\end{array}$ & $\begin{array}{l}\text { Northeastern Brazil (Seasonally Dry } \\
\text { Tropical Forests) }\end{array}$ \\
\hline $\begin{array}{l}\text { Pseudobombax campestre (Mart. \& } \\
\text { Zucc.) A. Robyns }\end{array}$ & Ganev 3489, Giulietti 1389 & $\begin{array}{l}\text { tern Brazil (Seasonally Dry } \\
1 \text { Forests) }\end{array}$ \\
\hline $\begin{array}{l}\text { Pseudobombax grandiflorum (Cav.) A. } \\
\text { Robyns }\end{array}$ & Thomas 9472, Carvalho & $\begin{array}{l}\text { Southeastern and Northeastern Brazil } \\
\text { (Atlantic Rain Forest) }\end{array}$ \\
\hline Pseudobombax guayasense A. Robyns & Asplund 17588, Robyns (1963) & $\begin{array}{l}\text { Ecuador (Seasonally Dry Tropical } \\
\text { Forests) }\end{array}$ \\
\hline $\begin{array}{l}\text { Pseudobombax longiflorum (Mart. \& } \\
\text { Zucc.) A. Robyns }\end{array}$ & Amorim 572, Carvalho-Sobrinho & Bolivia, Brazil, Paraguay (Savanna) \\
\hline $\begin{array}{l}\text { Pseudobombax marginatum (A. St.- } \\
\text { Hil., Juss. \& Cambess.) A. Robyns }\end{array}$ & Queiroz 3928, Carvalho-Sobrinho 580 & $\begin{array}{l}\text { Bolivia, Brazil, Paraguay, Peru (Seasonally } \\
\text { Dry Tropical Forests, Savanna) }\end{array}$ \\
\hline Pseudobombax maximum A. Robyns & Palmer 134, Robyns (1963) & $\begin{array}{l}\text { Colombia and Venezuela (Seasonally Dry } \\
\text { Tropical Forests) }\end{array}$ \\
\hline $\begin{array}{l}\text { Pseudobombax millei (Standl.) A. } \\
\text { Robyns }\end{array}$ & Pittier 8719, Robyns (1963) & Ecuador (Tropical Rain Forests) \\
\hline $\begin{array}{l}\text { Pseudobombax minimum Carv.-Sobr. } \\
\text { \& L. P. Queiroz }\end{array}$ & $\begin{array}{l}\text { Melo 2763, Carvalho-Sobrinho } 413 \text {, } \\
\text { Forzza } 1591\end{array}$ & Brazilian Central Plateau (Savanna) \\
\hline $\begin{array}{l}\text { Pseudobombax palmeri (S. Watson) } \\
\text { Dugand }\end{array}$ & Robyns (1963) & $\begin{array}{l}\text { Mexico (Seasonally Dry Tropical Forests } \\
\text { and Riparian Forests) }\end{array}$ \\
\hline $\begin{array}{l}\text { Pseudobombax parvifolium Carv.- } \\
\text { Sobr. \& L. P. Queiroz }\end{array}$ & $\begin{array}{l}\text { Queiroz 7343, Carvalho-Sobrinho } 572 \text {, } \\
\text { Carvalho-Sobrinho } 751\end{array}$ & $\begin{array}{l}\text { Northeastern Brazil (Seasonally Dry } \\
\text { Tropical Forests) }\end{array}$ \\
\hline $\begin{array}{l}\text { Pseudobombax septenatum (Jacq.) } \\
\text { Dugand }\end{array}$ & Robyns (1963) & $\begin{array}{l}\text { Nicaragua to Peru and Northern Brazil } \\
\text { (Tropical Rain Forests) }\end{array}$ \\
\hline $\begin{array}{l}\text { Pseudobombax simplicifolium A. } \\
\text { Robyns }\end{array}$ & $\begin{array}{l}\text { Andrade-Lima 1210, Moss s.n. (RB } \\
\text { 103602) }\end{array}$ & $\begin{array}{l}\text { Northeastern Brazil (Seasonally Dry } \\
\text { Tropical Forests) }\end{array}$ \\
\hline $\begin{array}{l}\text { Pseudobombax tomentosum (Mart. \& } \\
\text { Zucc.) A. Robyns }\end{array}$ & França 3629, Carvalho-Sobrinho 481 & Brazil and Paraguay (Savanna) \\
\hline $\begin{array}{l}\text { Scleronema micranthum (Ducke) } \\
\text { Ducke }\end{array}$ & $\begin{array}{l}\text { Alverson \& Steyermark (1997), Esteves } \\
\text { (2005) }\end{array}$ & $\begin{array}{l}\text { Venezuela and Northern Brazil (Tropical } \\
\text { Rain Forests) }\end{array}$ \\
\hline
\end{tabular}


supported as part of the Ochromeae, a small clade sister to the remaining Malvatheca (Bombacoideae + Malvoideae). Their inclusion in the analysis provided a rooting point for the trees outside the Adansonieae.

Selection and coding of characters - Morphological characters (table 2) are based on herbarium specimens and complemented by data from the following sources: Robyns (1963, 1964), Alverson \& Steyermark (1997), CascanteMarin (1997), Fernandez-Alonso (2001), Alverson \& Mori (2002) and Esteves (2005). Figures 1-9 ilustrate some of these characters.

Forty morphological characters were selected. Characters of plain shape (outline) were converted for

Table 2. Morphological characters utilized in the cladistic analysis of Pseudobombax and allied genera.

\begin{tabular}{|c|c|}
\hline Characters & Character states \\
\hline 1. Habit & {$[0]$ tree; [1] shrub } \\
\hline 2. Greenish strips on trunk (figure 2) & [0] absent; [1] present \\
\hline 3. Trunk (figure 4) & [0] not ventricose; [1] ventricose \\
\hline 4. Prickles on branches and trunk (figure 1) & [0] absent; [1] present \\
\hline 5. Leaves clustered in brachyblasts (figure 3 ) & [0] absent; [1] present \\
\hline *6. Division of leaf blade & $\begin{array}{l}\text { [0] simple; [1] } 3 \text { to } 5 \text { leaflets; [2] } 7 \text { to } 11 \text { leaflets; } \\
\text { [3] one leaflet }\end{array}$ \\
\hline 7. Leaflets jointed to petiole & {$[0]$ absent; $[1]$ present } \\
\hline 8. Length of petiole $(\mathrm{cm})$ & [0] $0.5-4.5 ;[1] 6-42$ \\
\hline 9. Apex of petiole widened & [0] absent; [1] present \\
\hline 10. Margin of leaf or leaflet & [0] entire; [1] lobed; [2] serrate \\
\hline 11. Adaxial surface of leaf/leaflet with simple hairs & [0] present; [1] absent \\
\hline 12. Abaxial surface of leaf/leaflet with simple hairs & [0] absent; [1] present \\
\hline 13. Veining pattern of leaf or leaflet & [0] pinnate; [1] palmate \\
\hline *14. Petiolule & $\begin{array}{l}\text { [0] absent or to } 0.1 \mathrm{~cm} \text { long; [1] } 0.2 \text { to } 2 \mathrm{~cm} \text {; [2] } \\
2.5 \text { to } 7.5 \mathrm{~cm}\end{array}$ \\
\hline 15. Inflorescence & {$[0]$ flowers isolate; $[1]$ cymes } \\
\hline$* 16$. Length of flower $(\mathrm{cm})$ & $\begin{array}{l}\text { [0] to } 3.9 ;[1] 4.5-6.0 ;[2] 6.5-12.5 ;[3] 13-17 ;[4] \\
17.5-35\end{array}$ \\
\hline 17. Calyx indumenta & {$[0]$ glabrous; $[1]$ indumented } \\
\hline 18. Glands on receptacle (figure 9) & [0] absent; [1] present \\
\hline 19. Margin of calyx & [0] lobed to lacinate; [1] truncate \\
\hline *20. Calyx: ratio length/width & {$[0]$ to $0.6 ;[1] 0.8-1.5 ;[2] 3$ or more } \\
\hline 21. Persistence of the calyx until the fruit & [0] persistent; [1] deciduous \\
\hline *22. Petal: ratio length/width & [0] to $4.5 ;[1] 6.0-11.5 ;[2] 14.0$ or more \\
\hline 23. Tufted hairs on abaxial side of petals (figure 8 ) & [0] absent; [1] present \\
\hline$* 24$. Ratio length of petal/length of calyx & [0] 1.3-3.0; [1] 4.5-12.0; [2] 15.0 or more \\
\hline 25. Staminodes & [0] absent; [1] present \\
\hline 26. Indument of staminal tube & [0] glabrous; [1] pubescent \\
\hline$* 27$. Number of fertile stamens & {$[0] 5 ;[1] 20-110 ;[2]>180$} \\
\hline 28. Filaments joining & {$[0]$ joined only at base; [1] joined to near apex } \\
\hline 29. Phalanges above staminal tube & [0] absent; [1] present \\
\hline 30. Shape of anthers & $\begin{array}{l}\text { [0] oblong, linear to reniform; [1] hipocrepiform; } \\
\text { [2] anfractuous }\end{array}$ \\
\hline *31. Number of carpels & {$[0] 3 ;[1] 5 ;[2]$ more than 5} \\
\hline 32. Indument of ovary & [0] glabrous; [1] indumented \\
\hline *33. Locules of the ovary & {$[0] 3-5 ;[1] 5 ;[2] 5-15$} \\
\hline 34. Ovules per locule & {$[0] 2 ;[1]$ many } \\
\hline 35. Fruit & [0] capsule; [1] samara; [2] drupe \\
\hline 36. Cross section of fruit & [0] circular; [1] 5-angled; [2] 5-winged \\
\hline 37. Fruit: ratio length/width & [0] 1.0-1.4 (figure 6); [1] 2.0-6.0; [2] more than 6.0 \\
\hline 38. Kapok (figure 7) & [0] absent; [1] present \\
\hline *39. Number of seeds per fruit & [0] up to five; [1] $15-30 ;$ [2] 50 or more \\
\hline 40. Shape of the seeds (figures 4-5) & [0] not angled; [1] angled \\
\hline
\end{tabular}

$*=$ ordered characters. 

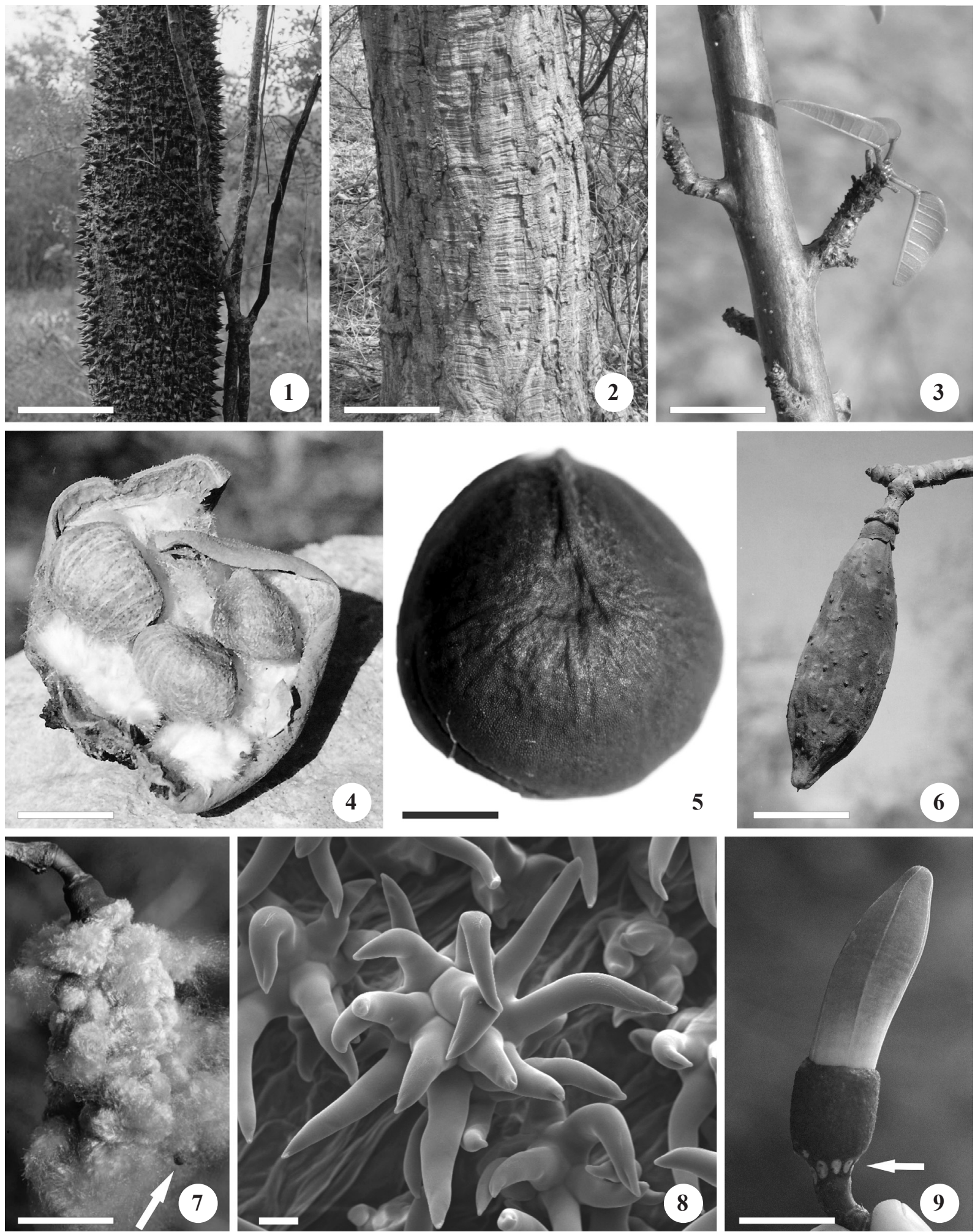

Figures 1-9. Some morphological characters used in the cladistic analysis of Pseudobombax. 1. Ventricose trunk covered with woody prickles of Ceiba glaziovii. 2. Trunk with grayish bark and strips of exposed greenish underbark of Pseudobombax simplicifolium. 3. Young leaves grouped in brachyblast of Pseudobombax simplicifolium. 4. Overgrown seeds of Bombacopsis retusa showing the flat plans of contact. 5. Seed of Pseudobombax minimum. 6. Indehisced capsule of Pseudobombax marginatum. 7. Dehisced capsule of Pseudobombax simplicifolium showing abundant kapok surrounding the seeds (arrow). 8. Tufted hairs (MEV) on the outer surface of a petal of Pseudobombax campestre. 9. Receptacular glands (arrow) of Pseudobombax simplicifolium. $\mathrm{Bar}=25 \mathrm{~cm}(1-2) ; 3 \mathrm{~cm}(3-4,9) ; 2 \mathrm{~mm}(5) ; 6 \mathrm{~cm}(6,7) ; 20 \mu \mathrm{m}(8)$. 
long $\times$ width ratios in order to minimize the subjectivity present in morphological terminology. Two analyses were performed considering unordered and ordered characters (10 multistate characters that express progression series). The data matrix (table 3 ) was edited in the software Nexus Data Editor (Page 2001).
Phylogenetic analysis - Maximum parsimony analyses were carried out in Paup 4.0b10 for Windows (Swofford 2000) using "Branching-and-Bound" algorithm. Bootstrap support (bs) was estimated in Paup using 1,000 replicates with 10 simple addition sequences using TBR, keeping up to 15 trees per replication. The most parsimonious trees

Table 3. Data matrix for the cladistic analysis of Pseudobombax and allied genera. Polymorphic characters are indicated by 'a' $(0+1)$, 'b' $(1+2)$, 'c' $(0+2)$, 'd' $(2+3+4)$, 'e' $(2+3),{ }^{\prime} f$ ' $(3+4) .(-=$ Inapplicable state; ? = Unknown state $)$.

\begin{tabular}{|c|c|c|c|c|}
\hline Taxon & 10 & 20 & 30 & 40 \\
\hline *Matisia ochrocalyx & $00000000-0000$ & $111-001002$ & 0000000111100 & 1110200000 \\
\hline *Ochroma pyramidale & $0000000-101$ & $111-021002$ & 1000011102 & 1111012120 \\
\hline *Scleronema micranthum & $00000000-0000$ & $0000-10000001$ & 0000000011100 & 000002000000 \\
\hline Adansonia digitata & 00100021102 & 000000011001 & $100000120 ? 0$ & 2121000010 \\
\hline Bombacopsis retusa & 00000011110000 & 0000000200111 & 1111002010 & 1011000011 \\
\hline Bombacopsis stenopetala & 000000020100 & 000000031011 & 1212011010 & 1111001011 \\
\hline Bombax ceiba & $000010202 ? 100$ & 1002021100 & 10000011011 & 1111001120 \\
\hline Cavanillesia arborea & $001000-100$ & 1 a $1-1000001$ & 1000001010 & 1110121000 \\
\hline Ceiba glaziovii & $00110 \mathrm{~b} 1102$ & 0001 a 200000 & 10000010000000 & 1011000120 \\
\hline Ceiba pentandra & $000102110 \mathrm{c}$ & 00011 a 0001 & $10000 ? 0$ a 02 & $1 ? 11000110$ \\
\hline Eriotheca crenulaticalyx & 0000000110000 & 0000000010000 & 1000000010000 & $11110001 ? 0$ \\
\hline Eriotheca gracillipes & a 000000111100 & 0001 a 001 a 0 & 1000000010000 & $11110011 ? 0$ \\
\hline Eriotheca longipedicellata & 00000021100 & 0001 a 10002 & 1000001000 & $1 ? 110011 ? 0$ \\
\hline Pachira aquatica & 000000021100 & 0001 a 40111 & 1212012010 & 1011001011 \\
\hline Pseudobombax calcicola & 0100010 a 10 & 0000000211110 & 01110 a 2001 & 1111012120 \\
\hline Pseudobombax campestre & 1100010110 & $00000201 \mathrm{a} 0$ & 0111002001 & 1111001120 \\
\hline Pseudobombax grandiflorum & 0 a 00020110 & 0001 a d 0111 & 01110 a 2001 & 1111011120 \\
\hline Pseudobombax guayasense & $00000 ? 0110$ & $000103 ? 110$ & 0111002011 & $11110 ? ? 12 ?$ \\
\hline Pseudobombax longiflorum & 000000020110 & 0002 a f0 0111 & $? 11110002001$ & $1 \mathrm{a} 11001120$ \\
\hline Pseudobombax marginatum & 11000020110 & 0100 a e 1110 & 01111012011 & 1111001120 \\
\hline Pseudobombax maximum & a 0000020110 & $? ? 010 \mathrm{f} ? 110$ & 0211002011 & 1111011120 \\
\hline Pseudobombax minimum & 01000020010 & 11000010111 & 011110002011 & 1111001120 \\
\hline Pseudobombax millei & 0000000100110 & ? ? $019 ? 311110$ & 01111012011 & $11110 ? ? 120$ \\
\hline Pseudobombax palmeri & 0000010110 & 1100 a d a 110 & 01110 a 2011 & 1111001120 \\
\hline Pseudobombax parvifolium & 01000010 a 10 & $111002111 \mathrm{a}$ & 01111012001 & $1 ? 1100 ? 120$ \\
\hline Pseudobombax septenatum & 01000020110 & 000 a a 20110 & 0011012011 & 1111011120 \\
\hline Pseudobombax simplicifolium & 01001300000 & 0000 a 20110 & 01111002001 & 1111001120 \\
\hline Pseudobombax tomentosum & 0 a 00020110 & 110 a 0 e 1111 & $01 ? 101212011$ & $111100112 ?$ \\
\hline
\end{tabular}

$*$ = Outgroups.

(MPTs) were analysed using Winclada (Nixon 2002). The characters were optimised using the "Fast optimization" (acctran) option.

\section{Results}

The maximum analysis considering 10 ordered characters resulted in nine MPTs, with 144 steps, consistency index (ci) 0.40, retention index (ri) 0.67 . The strict consensus tree is shown in figure 10 and one of the MPTs with optimized characters is shown in figure 11. The tribe Adansonieae appeared as monophyletic although presenting a low bootstrap support. The
Bombax-group was not supported as monophyletic due to the unresolved position of Eriotheca crenulaticalyx in the strict consensus tree.

At generic level, Pseudobombax was supported (bs 58\%) as monophyletic based on the following synapomorphies: petiole with widened, disciform apex (9), leaflets not jointed to the petiole (7) and calyx persistent and enlarged in the fruit (21). Pseudobombax was supported as sister to the Bombacopsis-Pachira clade (bs 64\%), based on the truncate calyx (19), narrow (tending to linear) petals (22), petals much longer than the calyx (24), presence of tufted hairs on the outer surface of the petals (23) 


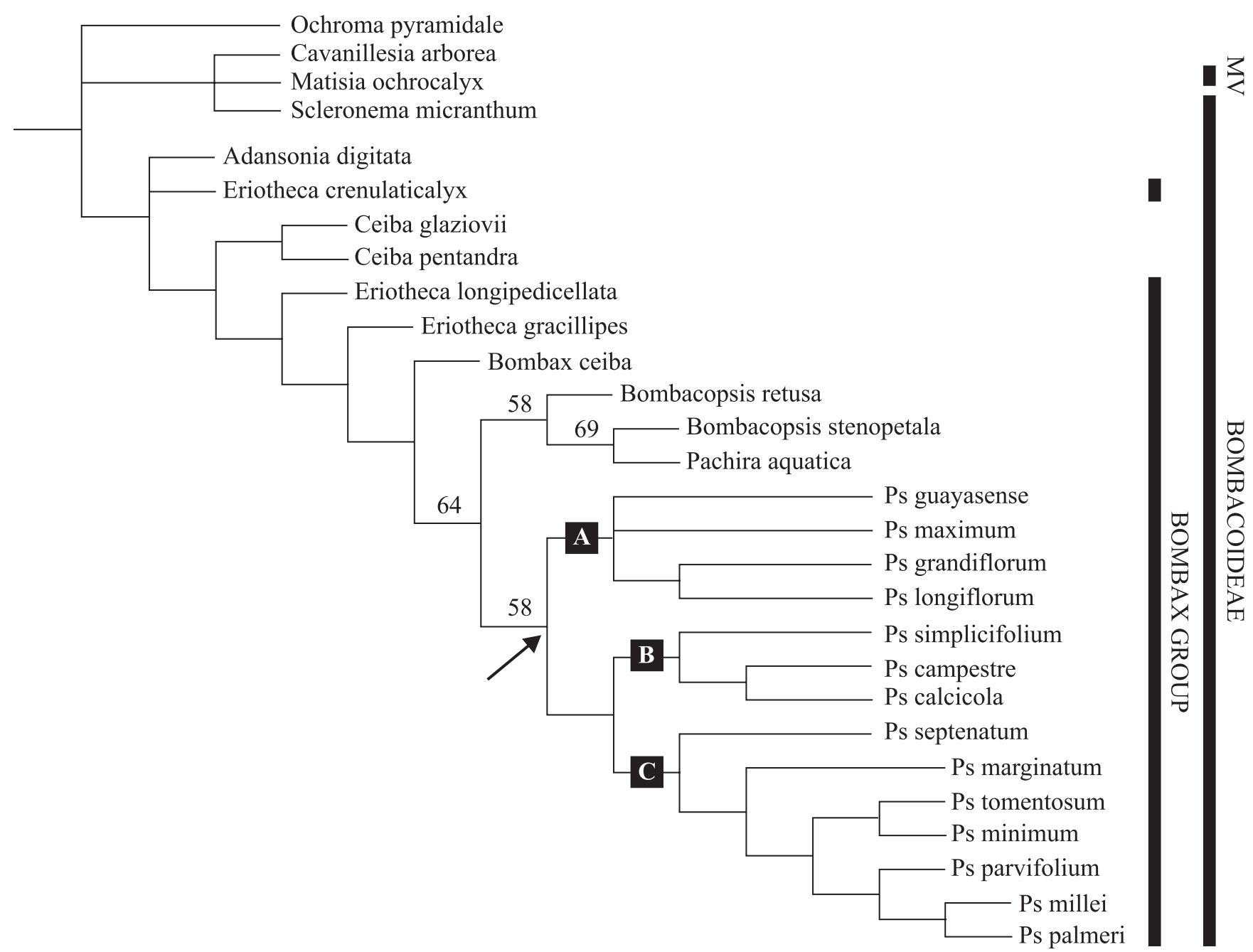

Figure 10. Strict consensus tree of the nine most parsimonious trees when considering 10 characters as ordered. Numbers above branches are bootstrap supports over 50\%. The genus Pseudobombax is indicated by an arrow. (MV = Malvoideae; Ps $=$ Pseudobombax $)$.

and numerous stamens (27). Pachira appeared nested within Bombacopsis forming a clade with moderate support (bs 58\%). The main characters that appeared as synapomorphic for this clade are the calyx almost as long as wide (20), the ovary covered by rudimentary hairs (32) and overgrown seeds (40), in addition to reversion to oblong anthers (30) and fruits without or with sparse kapok (38). The present analysis indicates the monophyly of Ceiba but with low support (bs $<50 \%)$. Eriotheca species appeared at a basal grade of the Bombax-group.

Within Pseudobombax, three main clades were recovered: clade A with four species ( $P$. guayasense, $P$. maximum, $P$. grandiflorum and $P$. longiflorum, clade B including three species ( $P$. calcicola, $P$. campestre and $P$. simplicifolium), and clade $\mathrm{C}$ including the remaining seven species ( $P$. marginatum, $P$. millei, $P$. minimum, P. palmeri, P. parvifolium, P. septenatum and P. tomentosum).

Clades B $+\mathrm{C}$ were defined by trunks with vertical greenish stripes (character 2). These stripes represent a chlorophyll-rich underbark which is exposed due to the opening of bands of the periderm leaving the trunk with a marbled aspect of grey and green. Clade B is characterised by reduction of leaflet number, reaching only one in $P$. simplicifolium (character 6) and androecium without phalanges (character 29). Clade $\mathrm{C}$ is characterised by the presence of a pubescent staminal tube (character 26). Within this clade, $P$. septenatum appears as sister of the remaining species because of the smaller ratio length/width of petals (character 22).

Cavanillesia appeared in a clade together with representatives of Scleronema (Bombacoideae) and Matisia (Malvoideae). The inclusion of Cavanillesia in 


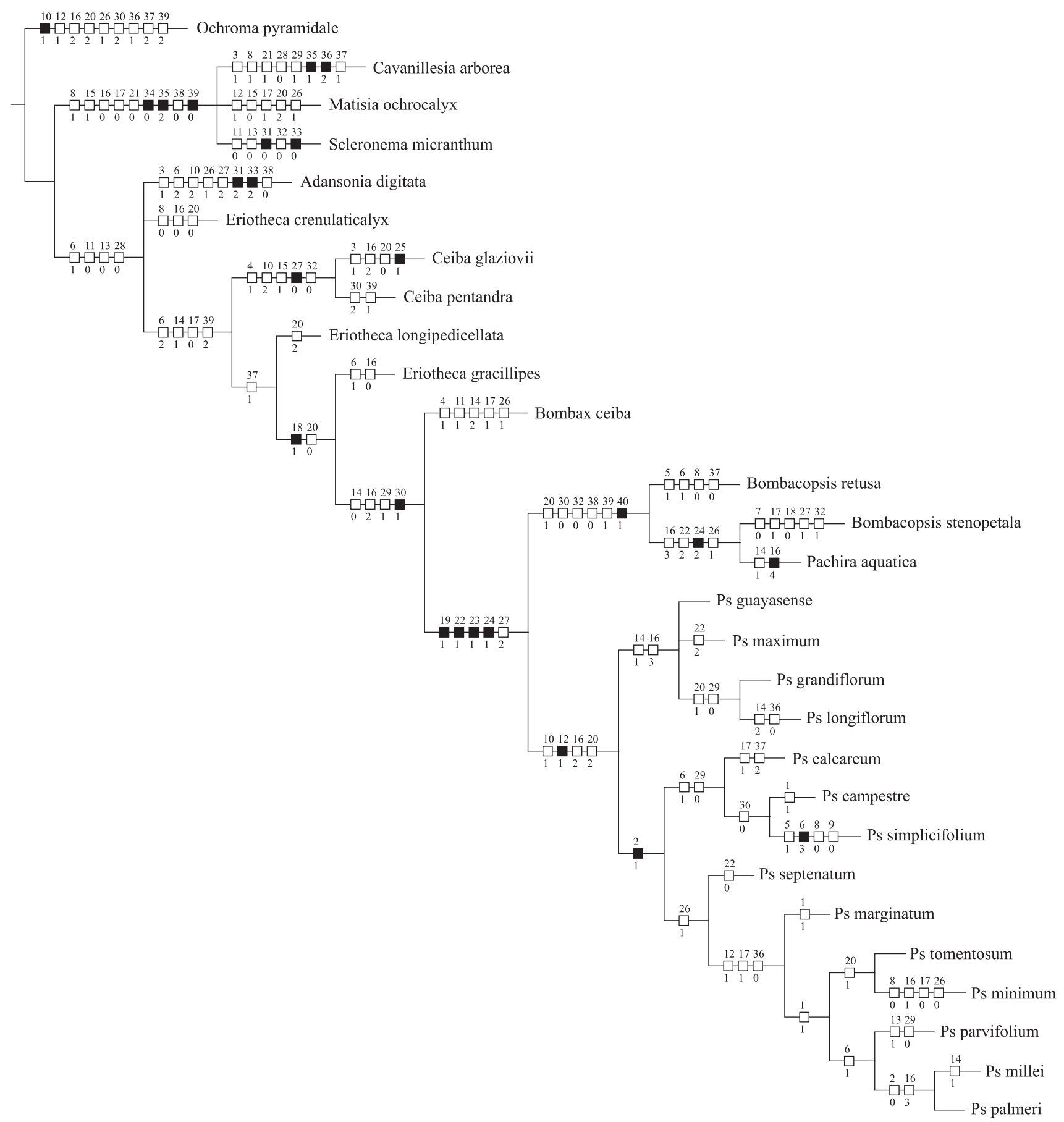

Figure 11. One of the nine most parsimonious trees, with acctran characters optimization. Numbers above boxes represent character and those below character state (table 2). (Ps = Pseudobombax).

Bombacoideae, sister to the Eriotheca longipedicellata - Pseudobombax palmeri clade, resulted in trees three steps longer.

The analysis considering unordered characters resulted in two MPTs, with 139 steps, ci 0.41 , ri 0.67. The topology of strict consensus tree differed from analysis with 10 ordered characters in relation to the positioning of Adansonia digitata, Bombax ceiba and Pseudobombax septenatum. Adansonia digitata appeared as sister to the clade BombacopsisPachira and Bombax ceiba as sister of Pseudobombax. Eriotheca appeared again as a paraphyletic group together with a Ceiba-clade. Within Pseudobombax, the same clades A, B, C were recovered, but with $P$. septenatum detached of clade $\mathrm{C}$ and as sister to a clade A + B (figure 12). 


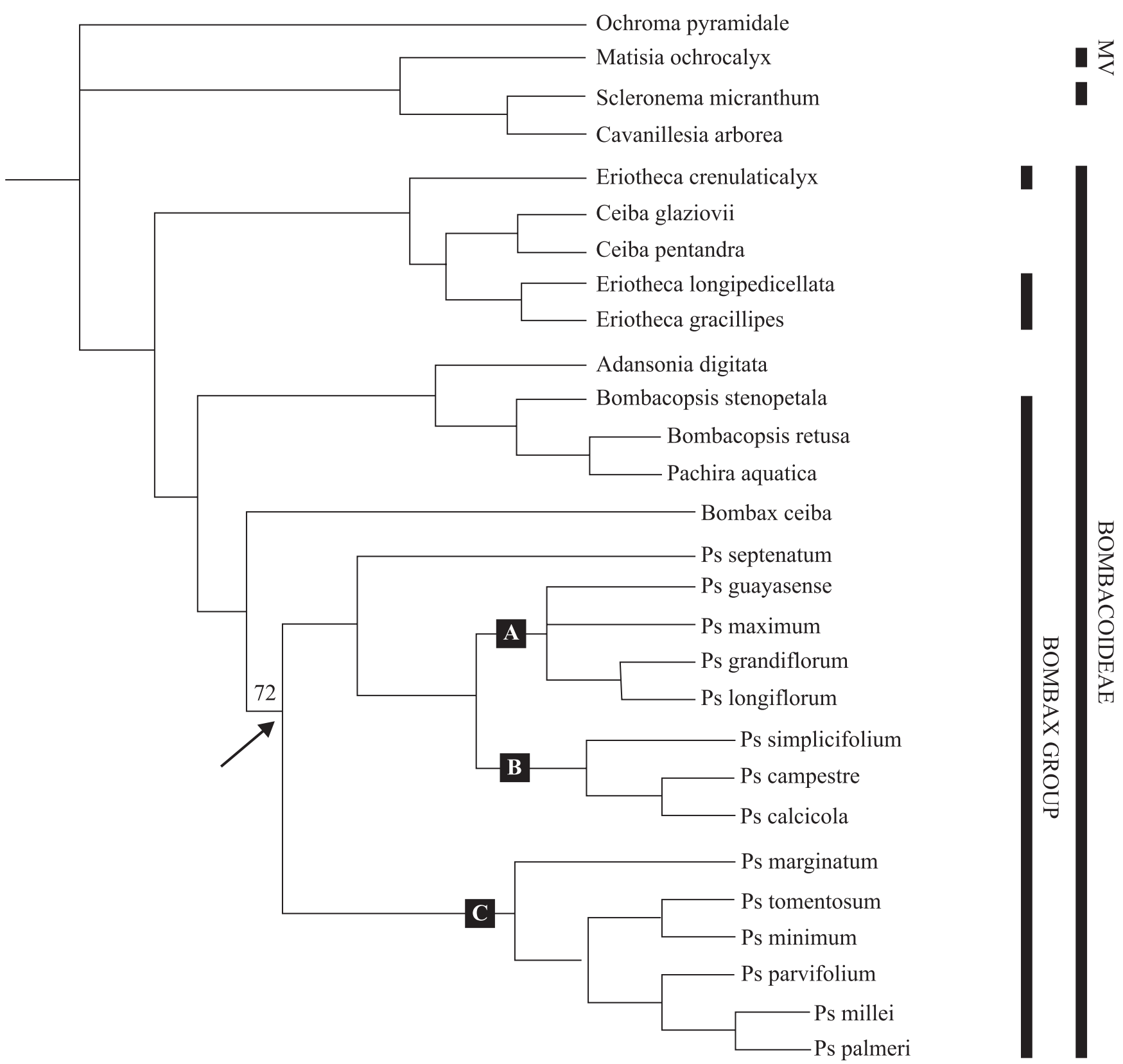

Figure 12. Strict consensus tree of the two most parsimonious trees when considering all characters unordered. Number above branch is bootstrap support over 50\%. The genus Pseudobombax is indicated by an arrow. (MV = Malvoideae; Ps $=$ Pseudobombax $)$.

\section{Discussion}

Effect of character ordering - The topologies resulting from the ordination of 10 characters showed no influence on the interpretation of the central questions of this study. In both analyses, Pseudobombax and the tribe Adansonieae appeared as monophyletic groups while the Bombax-group and the infrageneric taxa of Pseudobombax proposed by Robyns (1963) were not supported as monophyletic in any analysis. The results are discussed based on the analysis with 10 ordered characters because it showed greater congruence with the morphological evolution and biogeography of the group.

Phylogeny of the Bombax-group - The Bombax-group was not supported as monophyletic due the positioning of Eriotheca crenulaticalyx. This species appeared as sister to the remaining taxa of the Bombax-group in only one of the MPTs. As a consequence of the position of 
E. crenulaticalyx, and also E. longipedicellata, the genus Eriotheca was likewise not supported as monophyletic. The diagnostic characters of Eriotheca, such as jointed leaflets, small to medium size flowers, androecium with up to 140 stamens and absence of phalanges, appeared as plesiomorphies in the present work. This genus presents complex taxonomy (Martins 1993) and was previously considered as a synonym of Bombax (Schumann 1886, 1895, van den Brink 1924). A larger sample than that used here seems to be necessary to advance conclusions about its monophyly and its relationship to other Bombacoideae genera.

The position of set Bombax apart from the American Bombacopsis-Pachira-Pseudobombax clade supports the separation of this Old World genus from its American allied genera (Robyns 1963, Nicolson 1979). Pachira appeared nested within a paraphyletic Bombacopsis. This result supports recent proposals for merging these genera (Alverson 1994, Alverson \& Steyermark 1997, Fernández-Alonso 1998, 2003). However, because some of these characters are variable in Bombacopsis (Robyns 1963) a wider sampling is desirable.

Pseudobombax classification - The current classification of Pseudobombax was proposed by Robyns (1963) who recognised two subgenera: Monopseudobombax A. Robyns and Pseudobombax, the former characterised by simple leaves and including only one species, $P$. simplicifolium. The subgenus Pseudobombax was divided in two sections based on palynological characters: sect. Pseudobombax, including P. septenatum and P. munguba (Mart. \& Zucc.) Dugand, and sect. Heterosexinium A. Robyns for the remaining species. The present results do not support Robyns' (1963) classification. Pseudobombax simplicifolium (subgen. Monopseudobombax) is deeply nested in the Pseudobombax clade, rather than sister to the remaining species of subgen. Pseudobombax. Likewise, at sectional level, P. septenatum (sect. Pseudobombax) is nested among the species classified by Robyns (1963) in sect. Heterosexinium, also refuting the monophyly of this section.

Three main clades of Pseudobombax were recognised in the present study. Clade A includes species that seem to be related to sandy soils in Savanna or Seasonally Dry Forests, as is the case of $P$. guayasense, P. maximum and P. longiflorum, or restingas and Coastal Rain Forests as P. grandiflorum. This clade is supported by petiolulate leaflets (character 14) and 5-angulate fruits (36) and includes species with glabrous leaflets. Pseudobombax grandiflorum and P. longiflorum form a pair of closely related species (Robyns 1963), sharing a glabrous staminal tube without phalanges.

Clade B includes three species endemic to Seasonally Dry Tropical Forest area of north-eastern Brazil (Caatinga) that share triangulate bracteoles with a denticulate margin and a lower number of stamens (170 to 300$)$, oblong, narrow fruit (1.5-2.5 cm wide) and seeds uniform, evenly coloured. Pseudobombax simplicifolium shares with $P$. campestre glabrous leaflets with cordate base and with only 8-13 pairs of secondary veins and 170-220 stamens. The former occurs in areas of Caatinga with sandy soil while $P$. calcicola is restricted to limestone outcrops in upper São Francisco River valley, in the State of Bahia. Pseudobombax campestre is endemic to the Campos Rupestres of the Espinhaço Mountain Range, in the States of Bahia and Minas Gerais, in elevations above $900 \mathrm{~m}$.

The Clade $\mathrm{C}$ shows a trend to increase the number of stamens, usually between 400 and 1,500 per flower. However, in P. minimum, there is a reversion to c. 200 stamens. Most of the species included in the Clade $\mathrm{C}$ occurs in areas subject to seasonal climate, except for $P$. septenatum which occurs in the Amazonian Tropical Rain Forest. Within this group, P. marginatum, P. tomentosum and $P$. minimum are associated with Savanna (Cerrado) vegetation. Pseudobombax minimum is endemic to a strip of Cerrado in Eastern Goiás and the adjoining Western Bahia whereas P. parvifolium is known only from an area of Caatinga in Bahia and the adjoining Southern Sergipe.

Pseudobombax is more diverse in areas subject to a long dry season with xerophytic vegetation as is the case of the Caatinga in North-eastern Brazil and the Venezuelan Llanos (Carvalho-Sobrinho 2006) and the deciduous foliage of its species may be an adaptation to such climatic conditions. Contrary to Pseudobombax, the most basal taxa of the Bombax-group present a greater diversity in moist forests and its species are mostly evergreen as is the case with Eriotheca (Martins 1993), a genus with many species in the Atlantic and Amazonian forests, and with Bombacopsis and Pachira, that in sum comprise around 45 species (Alverson \& Steyermark 1997, Fernández-Alonso 1998), most of which distributed in the Amazon.

Morphological evolution - A palmately compound leaf blade is a putative synapomorphy of the Bombacoideae (Baum et al. 2004). Pseudobombax simplicifolium was described by Robyns (1963) as possessing simple leaves. However, it presents leaves with a pinnately veined brochidodromous pattern which is commonly 
found in leaflets of the palmately compound leaves of the Bombacoideae. We therefore interpret the leaves of $P$. simplicifolium as a reduced compound leaf with only one leaflet and thus not homologous to the simple leaf of Cavanillesia, Ochroma and the remaining Malvoideae.

The petiole widened at the apex and leaflets not jointed to the petiole were supported as derived states within the Bombacoideae and thus may be taken as synapomorphic for Pseudobombax. Leaflets with serrate margins seem to be plesiomorphic amongst the Bombacoideae since this condition is also found in Ceiba and Adansonia, and the entire margins may be synapomorphic for the Bombax-group.

It was possible to note a clear trend towards flower enlargement in the Bombax-group. Eriotheca is characterised by relatively small flowers while the species of the clade Bombax ceiba-Pseudobombax palmeri possess large $(6.5-12 \mathrm{~cm}$ long) or very large (13-35 cm long) flowers. This increasing flower size seems to be associated with an increment in stamens number and their organization in phalanges. According to Rao (1952) and van Heel (1966), a primitive flower of the Malvales would have five free stamens from which three evolutionary trends have arisen: increase in stamen number; arising of monothecate anthers from bithecate ones; and stamen connation. Recent studies had shown that numerous and joined stamens had arisen independently in several lineages of the Malvaceae (Alverson et al. 1999, Baum et al. 2004, von Balthazar et al. 2006). However, monothecate anthers seem to be an exclusive synapomorphy of the Malvatheca clade ([Ochromeae [Bombacoideae, Malvoideae]]). In the Bombax-group, these trends seem to be linked with an increasing specialization to bat pollination. Chiropterophilous plants are often trees with 'brush' flowers that shed their leaves during flowering period and tend to flower at the apex of the branches (Faegri \& van der Pij1 1971). Except for the deciduous foliage, these two traits are found in species of the Bombaxgroup, with crepuscular anthesis recorded for all studied species (Fischer et al. 1992). In Pseudobombax, the plants have also deciduous foliage during the flowering period, but it may be interpreted as a dual adaptation both to chiropterophily and to their preference for habitats subject to a long dry season since the plants flower mostly during the dry season.

Another evolutionary trend supported here is towards capsules with small and numerous seeds surrounded by abundant kapok, which is synapomorphic for the Ceiba glaziovii-Pseudobombax palmeri clade.
These characters may be interpreted as adaptations for wind dispersed seeds, a prevailing strategy among emergent plants (Willson 1992) as is the case of most Bombacoideae. In contrast to Pseudobombax, species of Pachira (including Bombacopsis) are more diverse in tropical rain forests where they form part of the canopy. This genus is supported by a reversion to fruits without or with sparse kapok and larger overgrown seeds (c. $2 \mathrm{~cm}$ long) which are dispersed by gravity when the fruits fall to the forest floor. Vogel (1980) found that in tropical primary forests, seeds with more massive cotyledons are common, probably because they can produce relatively robust seedlings in conditions where the sunlight may be limiting. Hence, the kapok seems to be unimportant for seed dispersal in these genera and large seeds may be a key innovation which allowed this genus to successfully colonize tropical rain forests.

Position of the genus Cavanillesia - Although this study focused on the phylogenetic relationships of Pseudobombax and allied genera, the results for Cavanillesia raised some interesting questions. This genus presents simple, palmately veined leaves and there is no agreement among different classification systems about its placement. Bentham \& Hooker (1862) placed it in the tribe Matisieae with the genera Durio, Hampea Schltdl., Matisia, Ochroma, Quararibea and Scleronema. Hutchinson (1967) removed Cavanillesia, Hampea and Scleronema to the tribe Hampeae. Takhtajan (1997) proposed a different arrangement with Cavanillesia, Durio and Scleronema (together with Coelostegia Bentham, Cullenia Wight, Kostermansia Soegeng and Neesia) in tribe Durioneae, Matisia, Huberodendron Ducke, Ochroma and Quararibea (with Bernoullia Oliv., Patinoa Cuatrec., Phragmotheca and Septotheca Ulbr.) in tribe Matisieae and Catostemma Benth. and Aguiaria Ducke in tribe Catostemateae.

Molecular phylogenetic studies supported the genera Hampea, Matisia and Quararibea (tribe Matisieae) as more related to the Malvoideae than to the Bombacoideae (Alverson et al. 1999, Baum et al. 1998, 2004, Nyffeler et al. 2005). According to Alverson et al. (1999), Cavanillesia is included in the Bombacoideae but they did not present trees supporting this hypothesis since Cavanillesia was removed from the analysis because it produced "an excessive number of trees". Likewise, Baum et al. (2004) considered intuitively that Cavanillesia must be included in the Bombacoideae clade but this conclusion was not tested. Although not conclusive, our results do not support this view since Cavanillesia appeared unresolved regarding the outgroups Matisia 
and Scleronema. Besides, Cavanillesia presents simple palmately veined leaves, traits shared with Ochroma and Matisia.

Recent molecular phylogenetic study carried out by Baum et al. (2004) supports Ochroma as part of a small clade sister to the larger BombacoideaeMalvoideae clade. This latter study also supports the close relationship of simple leaved genera Scleronema, Huberodendron and Catostemma, represented here by the former, to the Bombacoideae clade. However, unlike Ochroma, Matisia and Cavanillesia, the leaves of these genera present a pinnate, brochidodromous pattern similar to that found in the leaflets of the palmately compound leaves of the Bombacoideae. Therefore, the simple leaves found in genera presently included in Bombacoideae (the cited Scleronema, Huberodendron and Catostemma) may be not homologous to the simple leaves of the remaining Malvatheca. Rather, they could be interpreted as a result of the reduction of leaflets to one and hence be taken as homologous to a leaflet. In the present work, the pinnately veined leaves of Pseudobombax simplicifolium was unambiguously supported as derived from palmately compound leaves. Consequently, since Cavanillesia presents palmately veined simple leaves, similar to those found in Matisieae (Malvoideae) and Ochroma (Ochromeae), the hypothesis that it belongs to the Bombacoideae needs to be better investigated.

In summary, although a better sampling and use of molecular data should improve our understanding of relationships at generic level within the Bombax-group, the present work is to date the most comprehensive survey that supports the monophyly of Pseudobombax and establishes phylogenetic hypotheses of relationships within the genus. It also raises questions to be further investigated regarding the relationship between Pachira and Bombacopsis and the possible paraphyly of Eriotheca.

Acknowledgments - Thanks are due to Alessandro Rapini for critical reading of the manuscript. Capes provided a postgraduate fellowship for the first author and CNPq a researcher fellowship for the second one. Field work was supported by a grant from Fapesb (process no APR0199/2005) and by PPBIO/Semi-árido (MCT).

\section{References}

ALVERSON, W.S. 1994. New species and new combinations of Catostemma and Pachira (Bombacaceae) from the Venezuelan Guayana. Novon 4:3-8.
ALVERSON, W.S. \& MORI, S.A. 2002. Bombacaceae. In Guide to the vascular plants of central French Guiana, part 2. Dicotyledons (S.A. Mori, G. Cremers, C. Gracie, J.J. de Granville, S.V. Heald, M. Hoff \& J. Mitchell, eds.). Memoirs of the New York Botanical Garden 76:139-145.

ALVERSON, W.S. \& STEYERMARK, J.A. 1997. Bombacaceae. In Flora of the Venezuelan Guayana; Araliaceae - Cactaceae (P.E. Berry, B.K. Holst \& K. Yatskievych, eds.). Missouri Botanical Garden, Saint Louis, v.3, p.496-527.

ALVERSON, W.S., WHITLOCK, B.A., NYFFELER, R., BAYER, C. \& BAUM, D.A. 1999. Phylogeny of the core Malvales: evidence from $n d h \mathrm{~F}$ sequence data. American Journal of Botany 86:1474-1486.

BAUM, D.A., ALVERSON, W.S. \& NYFFELER, R. 1998. A durian by any other name: taxonomy and nomenclature of the core Malvales. Harvard Papers in Botany 3:315330.

BAUM, D.A., SMITH, S.D., YEN, A., ALVERSON, W.S., NYFFELER, R., WHITLOCK, B.A. \& OLDHAM, R.L. 2004. Phylogenetic relationships of Malvatheca (Bombacoideae and Malvoideae; Malvaceae sensu lato) as inferred from plastid DNA sequences. American Journal of Botany 91:1863-1871.

BAYER, C., FAY, M.F, BRUIJN, A.Y. DE, SAVOLAINEN, V., MORTON, C.M., KUBITZKI, K., ALVERSON, W.S. \& CHASE, M.W. 1999. Support for an expanded family concept of Malvaceae within a recircumscribed Order Malvales: a combined analysis of plastid $a t p \mathrm{~B}$ and $r b c$ L DNA sequences. Botanical Journal of the Linnean Society 129:267-303.

BENTHAM, G. \& HOOKER, J.D. 1862. Genera Plantarum. L. Reeve \& Co., London, v.1.

CARVALHO-SOBRINHO, J.G. 2006. O gênero Pseudobombax Dugand (Malvaceae s.l., Bombacoideae) no Estado da Bahia, Brasil. Dissertação de mestrado, Universidade Estadual de Feira de Santana, Feira de Santana.

CARVALHO-SOBRINHO, J.G. \& QUEIROZ, L.P. 2010. Three new species of Pseudobombax (Malvaceae, Bombacoideae) from Brazil. Novon 20:13-20.

CASCANTE-MARIN, A. 1997. La familia Bombacaceae (Malvales) en Costa Rica. Brenesia 47-48:17-36.

CRONQUIST, A. 1981. An integrated system of classification of flowering plants. Columbia University Press, New York.

DUGAND, A. 1943. Revalidacion de Bombax ceiba L. como espécie típica del género Bombax L. y descripcion de Pseudobombax gen. nov. Caldasia 2:47-68.

ESTEVES, G.L. 2005. Flora da Reserva Ducke: Bombacaceae. Rodriguésia 56:115-124.

FAEGRI, K. \& VAN DER PIJL, L. 1971. The principles of pollination ecology, ed. 2. Pergamon Press, Oxford and New York. 
FERNÁNDEZ-ALONSO, J.L. 1998. Novedades taxonômicas, corológicas y nomenclaturales em el gênero Pachira Aubl. (Bombacaceae). Anales del Jardin Botánico de Madrid 52:305-314.

FERNÁNDEZ-ALONSO, J.L. 2001. Bombacaceae neotropicae novae vel minus cognitae 5. Novedades en Pseudobombax Dugand y sinopsis de las especies Colombianas. Revista de la Academia Colombiana de Ciéncias Exactas, Físicas y Naturales 25:467-476.

FERNÁNDEZ-ALONSO, J.L. 2003. Bombacaceae neotropicae novae vel minus cognitae VI. Novedades en los géneros Cavanillesia, Eriotheca, Matisia y Pachira. Revista de la Academia Colombiana de Ciéncias 27: 25-37.

FISCHER, E.A., JIMENEZ, F.A. \& SAZIMA, M. 1992. Polinização por morcegos em duas espécies de Bombacaceae na Estação Ecológica de Juréia, São Paulo. Revista Brasileira de Botânica 15:67-72.

GIBBS, P.E. \& SEMIR, J. 2003. A taxonomic revision of the genus Ceiba Mill. (Bombacaceae). Anales del Jardin Botánico de Madrid 60:259-300.

HUTCHINSON, J. 1967. The genera of flowering plants. Dicotyledons. Clarendon Press, Oxford, v.2.

IPNI - The International Plant Names Index - 2010. Pseudobombax. http://www.ipni.org (acesso em 27/08/2010).

JUDD, W.S. \& MANCHESTER, S.R. 1997. Circumscription of Malvaceae (Malvales) as determined by a preliminary cladistic analysis of morphological, anatomical, palynological and chemical characters. Brittonia 49: 384-405.

MARTINS, V.L.C. 1993. Espécies brasileiras de Eriotheca Schott. \& Endl. (Bombacaceae). Dissertação de mestrado, Universidade Federal do Rio de Janeiro, Rio de Janeiro.

NICOLSON, D.H. 1979. Nomenclature of Bombax ceiba (Bombacaceae) and Cochlospermum (Cochlospermaceae) and their type species. Taxon 28:367-373.

NIXON, K.C. 2002. WinClada computer program, version 1.00.18-OptCodeFix (Beta). K.C. Nixon, Ithaca, New York.

NYFFELER, R., BAYER, C., ALVERSON, W., YEN, A., WHITLOCK, B., CHASE, M. \& BAUM, D. 2005. Phylogenetic analysis of the Malvadendrina clade (Malvaceae s.1.) based on plastid DNA sequences. Organisms Diversity \& Evolution 5:109-123.
PAGE, R.D.M. 2001. NDE, Nexus Data Editor for Windows, version 0.5.0. http://taxonomy.zoology.gla.ac.uk/rod/ NDE/nde.html (acesso em 27/08/2009).

RAO, C.V. 1952. Floral anatomy of some Malvales and its bearing on the affinities of families included in the order. Journal of the Indian Botanical Society 21: 171-203.

ROBYNS, A. 1963. Essai de monographie du genre Bombax L. s.l. (Bombacaceae). Bulletin du Jardin Botanique de l'État a Bruxelles 33:1-315.

ROBYNS, A. 1964. Flora of Panama. Part IV. Bombacaceae. The Annals of Missouri Botanical Garden 51:37-68.

SCHUMANN, K. 1886. Bombacaceae. In Flora Brasiliensis (C.F.P. Martius, A.G. Eichler \& I. Urban, eds.). F. Fleischer, Lipsiae, v.12, pars 3, p.201-250, tab. 40-50.

SCHUMANN, K. 1895. Bombacaceae. In Die natürlichen Pflanzenfamilien (A. Engler \& K. Prantl, eds.). Verlag von Wilhelm Engelmann, Leipzig IV. Teil, Abt. 6, p.5368.

STEYERMARK, J.A. \& STEVENS, D. 1998. Notes on Rhodognaphalopsis and Bombacopsis (Bombacaceae) in the Guayanas. Annals of the Missouri Botanical Garden 75:396-398.

SWOFFORD, D.L. 2000. PAUP: Phylogenetic analysis using parsimony, version 4.0d64 and 4.0b1. Sinauer, Sunderland.

TAKHTAJAN, A.L. 1997. Diversity and classification of flowering plants. Columbia University Press, New York.

VAN DEN BRINK, R.C.B. 1924. Revisio Bombacacearum. Bulletin du Jardin Botanique de Buitenzorg 6:161240.

VAN HEEL, W.A. 1966. Morphology of the androecium in Malvales. Blumea 13:177-394.

VOGEL, E.F. DE. 1980. Seedlings of Dicotyledons. Centre for Agricultural Publishing and Documentation, Wageningen.

VON BALTHAZAR, M., SCHÖNENBERGER, J., ALVERSON, W.S., JANKA, H., BAYER, C. \& BAUM, D.A. 2006. Structure and evolution of the androecium in the Malvatheca clade (Malvaceae s.l.) and implications for Malvaceae and Malvales. Plant Systematics and Evolution 260:171-197.

WILLSON, M.F. 1992. The ecology of seed dispersal. In Seeds: the ecology of regeneration in plant communities (M. Fenner, ed.). University of Southampton, Southampton, p.61-86. 
